九州大学学術情報リポジトリ

Kyushu University Institutional Repository

\title{
Properties of Active Substance, BCF, which Synergistically Enhances the Antimicrobial Activity of Hexametaphosphate
}

Tsutsumi, Masakazu

Laboratory of Food Hygienic Chemistry, Faculty of Agriculture, Kyushu University

Mi yamoto, Takahisa

Laboratory of Food Hygienic Chemistry, Faculty of Agriculture, Kyushu University

Suda, Ikuo

Laboratory of Food Hygienic Chemistry, Faculty of Agriculture, Kyushu University

Watanabe, Tadao

Laboratory of Food Hygienic Chemistry, Faculty of Agriculture, Kyushu University

https://doi.org/10.5109/23740

出版情報：九州大学大学院農学研究院紀要. 26 (2/3)，pp.71-78，1982-02. Kyushu University バージョン：

権利関係 : 
J. Fac. Agr., Kyushu Univ., $26(2 \cdot 3), 71-78$ (1982)

\title{
Properties of Active Substance, BCF, which Synergistically Enhances the Antimicrobial Activity of Hexametaphosphate
}

\author{
Masakazu Tsutsumi, Takahisa Miyamoto, Ikuo Suda \\ and Tadao Watanabe \\ Laboratory of Food Hygienic Chemistry, Faculty of Agriculture, \\ Kyushu University 46-09, Fukuoka 812
}

(Received July 29, 1981)

\begin{abstract}
An active substance named BCF was found in the culture broth of Bacillus subtilis. This substance synergistically enhanced the antibacterial activity of hexametaphosphate against gram-negative bacteria such as Escherichia coli and markedly weakened the salt tolerance of some bacteria such as Aerobacter aerogenes and Staphylococcus aureus, and yet no antibacterial activity was shown in itself. BCF was extractable with n-butanol at $\mathrm{pH} 9.0$ and dialyzable against water using cellulose tubing; besides, it was stable at alkaline $\mathrm{pH}$ and to heat also.
\end{abstract}

\section{INTRODUCTION}

Polyphosphates such as hexametaphosphate (HP) or ultraphosphate are effective against most gram-positive bacteria, but are inactive against most gram-negative bacteria (Tsutsumi et al., 1976). Polyphosphates, however, show strong growth inhibition against gram-negative bacteria in the presence of sodium cholate or glycerol monocaprate (Tsutsumi et al., 1977).

In a series of investigations we found an active substance named BCF in the culture broth of Bacillus subtilis, which synergistically enhanced the antibacterial activity of polyphosphates against Escherichia coli. We also found out the fact that the salt tolerance of Staphylococcus aureus was markedly weakened by adding $\mathrm{BCF}$. Whereas no antibacterial activity was shown in $\mathrm{BCF}$ alone.

Being interested in studying such bacteriologically active substance, we have tried purifying and characterizing $B C F$. In this paper, we tried elucidating the properties of $\mathrm{BCF}$ first though it is not yet isolated in a pure state.

\section{MATERIALS AND METHODS}

\section{Strains}

Escherichia coli IFO 3301, Pseudomonas aureofacience IFO 3521, Bacillus cereus IFO 3060, Saccharomyces cerevisiae IFO 2044 and Torulopsis etchellsii IFO 1229 were obtained from Institute for Fermentation, Osaka.

Bacillus subtilis and Aerobacter aerogenes were generously provided by a certain Institute. 


\section{Media and cultural conditions}

Nutrient broth containing $1 \%$ polypeptone and 1\% Ehrlich meat extract was used as a growth medium for bacteria. The broth $\mathrm{pH}$ was adjusted to 7.0.

Sabouraud medium ( $\mathrm{pH} 7.0$ ) improved by addition of $0.2 \%$ yeast extract was used for yeasts. The culture was carried out at $30^{\circ} \mathrm{C}$ for 24 hours on a reciprocal shaker.

\section{Determination of antibacterial activity}

The antibacterial activity of $\mathrm{BCF}$ was routinely determined on Escherichia coli in the presence of $\mathrm{HP}$. To $5 \mathrm{ml}$ of $2 \%$ broth were added $3 \mathrm{ml}$ of the culture filtrate (BCF-CF) containing $\mathrm{BCF}, 1 \mathrm{ml}$ of sterile $\mathrm{HP}, 0.5 \mathrm{ml}$ of sterile water and $0.5 \mathrm{ml}$ of overnight culture of Escherichia coli growing in $1 \%$ broth, and the inoculated medium was incubated at $30^{\circ} \mathrm{C}$ for 20 hours with shaking. The same volume of sterile water was added instead of the culture filtrate and HP in control experiment 1 , the culture filtrate in control experiment 2 and HP in control experiment 3 . The turbidity $\left(\mathrm{OD}_{660}\right)$ of the overnight culture used was adjusted to 0.3 with sterile water before use. Sodium chloride $(\mathrm{NaCl})$ or $\mathrm{HP}$ was added to give the final concentrations indicated.

Growth was routinely monitored by the change in absorbance of the culture with a colorimeter fitted with a red 660 filter and graded from - through $\#$ as follows: - , no growth $\left(\mathrm{OD}_{660}=0 \sim 0.04\right)$; \pm , very slight growth $\left(\mathrm{OD}_{660}=\right.$ $0.05 \sim 0.09) ;+$, moderate growth $\left(\mathrm{OD}_{660}=0.1 \sim 0.4\right) ; \mathrm{H}$, good growth $\left(\mathrm{OD}_{660}=\right.$ above 0.4 ).

\section{n-Butanol extraction}

The culture broth $(20 \mathrm{ml})$ containing $\mathrm{BCF}$ was adjusted to $\mathrm{pH} 5.0, \mathrm{pH} 7.0$ and $\mathrm{pH} 9.0$ with $\mathrm{HCl}$ or $\mathrm{NaOH}$ solution, and then the same volume of n-butanol was added. After shaking vigorously, $\mathrm{n}$-butanol extracts were separated from the broth and dried in vacuo at $40^{\circ} \mathrm{C}$. The residues were dissolved in $10 \mathrm{ml}$ of $\mathrm{n}$-butanol and the insoluble materials were removed by centrifugation. After the supernatant was evaporated to dryness in vacuo at $40^{\circ} \mathrm{C}$, the residues were dissolved in $20 \mathrm{ml}$ of water. This was named $\mathrm{BCF}-\mathrm{Buol}$ and those extracted at $\mathrm{pH} 5.0$, $\mathrm{pH} 7.0$ and $\mathrm{pH} 9.0$ were named $\mathrm{BCF}-\mathrm{Buol}-5, \mathrm{BCF}-\mathrm{Buol}-7$ and $\mathrm{BCF}-$ Buol -9 , respectively.

\section{RESULTS}

\section{Accumulation of BCF in the culture broth}

In the growth curve of Bacillus subtilis, the accumulation of $\mathrm{BCF}$ began to appear at mid-logarithmic phase and reached the highest level at early stationary phase (data not shown).

After Bacillus subtilis was cultured at different temperatures from $20^{\circ} \mathrm{C}$ to $45^{\circ} \mathrm{C}$, the cells were separated from the culture broth by centrifugation and then the activity in the supernatant was determined in the presence of HP. 
Though the maximal activities were detected when the bacterium was grown at $30^{\circ} \mathrm{C}$ and $35^{\circ} \mathrm{C}$, no activity was observed in the cells grown at $45^{\circ} \mathrm{C}$ (data not shown).

\section{Antimicrobial activity of BCF}

To $5 \mathrm{ml}$ of $2 \%$ broth were added $3 \mathrm{ml}$ of the culture filtrate containing $\mathrm{BCF}, 1.5 \mathrm{ml}$ of sterile water and $0.5 \mathrm{ml}$ of microorganisms suspension $\left(\mathrm{OD}_{660}=\right.$ $0.3)$, and the inoculated cultures were incubated at $30^{\circ} \mathrm{C}$ for 20 hours.

Table 1 shows that $\mathrm{BCF}-\mathrm{CF}$ alone was inactive against all microorganisms tested.

\section{Synergism between BCF-CF and other chemicals}

The synergistic effects between $\mathrm{BCF}-\mathrm{CF}$ and other chemicals ( $\mathrm{HP}, \mathrm{NaCl}$, sodium cholate or glycerol monocaprate) were determined using some microorganisms. The effects between $\mathrm{BCF}-\mathrm{CF}$ and either $\mathrm{HP}$, sodium cholate or glycerol monocaprate against gram-positive microorganisms were not determined because these chemicals alone showed the antimicrobial activity against these microorganisms.

a) In the case of Escherichia coli

1) $\mathrm{BCF}-\mathrm{CF}$ and $\mathrm{HP}$

Growth was always observed in the control experiments 1 and 3, and therefore the rest omitted the data of these results.

2) $\mathrm{BCF}-\mathrm{CF}$ and $\mathrm{NaCl}$

3) $\mathrm{BCF}-\mathrm{CF}$ and sodium cholate

4) $\mathrm{BCF}-\mathrm{CF}$ and glycerol monocaprate

Table 1. Antimicrobial activity of $\mathrm{BCF}-\mathrm{CF}$ against several microorganisms. Growth was graded from-(no growth), \pm (very slight growth), + (moderate growth) through + (good growth).

\begin{tabular}{|c|c|}
\hline Microorganisms & Growth \\
\hline E. coli & $\#$ \\
\hline P. aureofacience & $\#$ \\
\hline S. aureus & $H$ \\
\hline B. cereus & H \\
\hline$B$. megaterium & H \\
\hline S. cerevisiae & H. \\
\hline T. etchellsii & H \\
\hline
\end{tabular}

Table 2. Synergism between $\mathrm{BCF}-\mathrm{CF}$ and HP against $E$. coli. Symbols are the same as in Table 1.

\begin{tabular}{|c|c|c|c|c|}
\hline \multirow{2}{*}{$\mathrm{HP}(\%)$} & \multicolumn{4}{|c|}{ Growth } \\
\hline & Control 1 & Control 2 & Control 3 & Test \\
\hline $\begin{array}{r}0 \\
0.25 \\
0.50 \\
0.75 \\
1.00\end{array}$ & $\begin{array}{l}H \\
H \\
H \\
H \\
H\end{array}$ & $\begin{array}{l}H \\
H \\
H \\
H \\
H\end{array}$ & $\begin{array}{l}H \\
H \\
H \\
H \\
H\end{array}$ & $\begin{array}{l}H \\
- \\
-\end{array}$ \\
\hline
\end{tabular}


Table 3. Synergism between $\mathrm{BCF}-\mathrm{CF}$ and $\mathrm{NaCl}$ against E. coli. Symbols are the same as in Table 1.

\begin{tabular}{ccc} 
& \multicolumn{2}{c}{ Growth } \\
\cline { 2 - 2 }$(\%)$ & Control 2 & Test \\
0 & +1 & 1 \\
1 & + & 4 \\
2 & + & + \\
3 & + & + \\
4 & + & - \\
5 & + & - \\
6 & + & - \\
7 & + & - \\
9 & + & +
\end{tabular}

Table 4. Synergism between BCF-CF and cholate against E. coli. Symbols are the same as in Table 1.

Cholate (\%) $\frac{\text { Growth }}{\text { Control } 2}$ Test

$\begin{array}{rrr}0 & H & \# \\ 0.025 & H & H \\ 0.050 & H & \# \\ 0.075 & H & H \\ 0.100 & H & H\end{array}$

Table 5. Synergism between $\mathrm{BCF}-\mathrm{CF}$ and glycerol monocaprate against E. coli. Symbols are the same as in Table 1 .

\begin{tabular}{ccc}
\hline \multirow{2}{*}{ Glycerol monocaprate } & \multicolumn{2}{c}{ Growth } \\
\cline { 2 - 3 } & Control 2 & Test \\
\hline 0 & $H$ & + \\
0.025 & + & + \\
0.050 & + & + \\
0.075 & + & + \\
0.100 & + & + \\
\hline
\end{tabular}

The synergistic effects between $\mathrm{BCF}-\mathrm{CF}$ and either $\mathrm{HP}$ or $\mathrm{NaCl}$ was observed (Tables 2 and 3 ), but not either sodium cholate or glycerol monocaprate (Tables 4 and 5 ).

b) In the case of Aerobacter aerogenes

1) $\mathrm{BCF}-\mathrm{CF}$ and $\mathrm{NaCl}$

The synergistic effect between $\mathrm{BCF}-\mathrm{CF}$ and $\mathrm{NaCl}$ against Aerobacter aerogenes was apparent. As the effects between BCF-CF and either HP, sodium cholate or glycerol monocaprate were similar to the results of Escherichia coli, the data were omitted. In the case of Pseudomonas aureofacience, the data were similar to the results of Escherichia coli.

c) In the case of Staphylococcus aureus 
Table 6. Synergism between $\mathrm{BCF}-\mathrm{CF}$ and $\mathrm{NaCl}$ against $A$. aerogenes. Symbols are the same as in Table 1.

\begin{tabular}{ccc} 
& \multicolumn{2}{c}{ Growth } \\
\cline { 2 - 3 } $\mathrm{NaCl}(\%)$ & Control 2 & Test \\
\hline 0 & + & + \\
1 & + & - \\
2 & + & - \\
3 & + & - \\
4 & + & - \\
5 & + & - \\
6 & + & - \\
7 & + & - \\
8 & - & - \\
\hline
\end{tabular}

Table 7. Synergism between $\mathrm{BCF}-\mathrm{CF}$ and $\mathrm{NaCl}$ against Staph. aureus. Symbols are the same as in Table 1.

\begin{tabular}{|c|c|c|}
\hline \multirow{2}{*}{$\mathrm{NaCl}(\%)$} & \multicolumn{2}{|c|}{ Growth } \\
\hline & Control 2 & Test \\
\hline 0 & $H$ & $H$ \\
\hline 1 & $H$ & $H$ \\
\hline 2 & H & H \\
\hline 3 & H & H \\
\hline 4 & $\mathrm{H}$ & + \\
\hline 5 & it & - \\
\hline 6 & th & - \\
\hline 7 & Ht & - \\
\hline 8 & $H$ & - \\
\hline 9 & H & - \\
\hline 10 & H & - \\
\hline 11 & $H$ & - \\
\hline 12 & + & - \\
\hline 13 & + & - \\
\hline 14 & - & - \\
\hline 15 & - & - \\
\hline
\end{tabular}

1) $\mathrm{BCF}-\mathrm{CF}$ and $\mathrm{NaCl}$

Staphylococcus aureus could grow in a medium containing $13 \% \mathrm{NaCl}$. The salt tolerance of the bacterium, however, was markedly weakened by adding BCF-CF, as shown in Table 7.

d) In the case of Saccharomyces cerevisiae

1) $\mathrm{BCF}-\mathrm{CF}$ and $\mathrm{NaCl}$

No synergistic effect was observed (Table 8 ).

\section{Properties of BCF}

As described in Method, $\mathrm{BCF}$ was extracted with n-butanol. Each BCFBuol alone was inactive against the test microorganisms (data not shown); however, BCF-Buol-7 and BCF-Buol-9 were effective against Escherichia coli in the presence of HP, as shown in Table 9.

The n-butanol extracts (BCF-Buol-9) were stable between $\mathrm{pH}$ values $7 \sim 12$ 
Table 8. Synergism between $\mathrm{BCF}-\mathrm{CF}$ and $\mathrm{NaCl}$ against Sacch. cerevisae. Symbols are the same as in Table 1.

\begin{tabular}{ccc}
\hline \multirow{2}{*}{$\mathrm{NaCl}(\%)$} & \multicolumn{2}{c}{ Growth } \\
\cline { 2 - 3 } & Control 2 & Test \\
\hline 0 & + & + \\
1 & + & + \\
2 & + & + \\
3 & + & + \\
4 & \pm & \pm \\
5 & - & - \\
6 & - & - \\
\hline
\end{tabular}

Table 9. Synergism between each BCF-Buol and $\mathrm{HP}$ against $E$. coli. Symbols are the same as in Table 1.

\begin{tabular}{|c|c|c|c|c|}
\hline \multirow{2}{*}{$\mathrm{BCF}-\mathrm{Buol}$} & \multicolumn{4}{|c|}{ Growth } \\
\hline & Control 1 & Control 2 & Control 3 & Test \\
\hline $\begin{array}{l}\text { BCF-Buol-5 } \\
\text { BCF-Buol-7 } \\
\text { BCF-Buol-9 }\end{array}$ & $\begin{array}{l}H \\
H \\
H\end{array}$ & $\begin{array}{l}H \\
H \\
H\end{array}$ & $\begin{array}{l}H \\
H \\
H\end{array}$ & 11 \\
\hline
\end{tabular}

when left for $60 \mathrm{~min}$ at room temperatures between $\mathrm{pH}$ values $2 \sim 12$ (data not shown). When kept for $30 \mathrm{~min}$ in boiling water, for $20 \mathrm{~min}$ at $120^{\circ} \mathrm{C}$ (in autoclave) or for 72 days at $-20^{\circ} \mathrm{C}$, the extracts were stable (data not shown).

The $\mathrm{n}$-butanol extracts (BCF-Buol-9) were dialyzed against running water (deionized) using Cellulose tubing (Visking Co.). The dialyzed extracts were withdrawn at intervals and then the activities were determined in the presence of HP. The active substance (BCF) in the extracts completely disappeared by dialysis (data not shown).

\section{DISCUSSION}

Polyphosphates such as hexametaphosphate show antimicrobial action; therefore their application as food preservatives has been studied. Polyphosphate, however, were inactive against most gram-negative bacteria.

The fact may be disadvantageous as the preservatives, hence we proposed some attempts to overcome the difficulties by use of the substances enhancing synergistically the activity of HP against gram-negative bacteria (Tsutsumi et al., 1977; Watanabe et al., 1977; Watanabe et al., 1979). In a series of investigation an active substance named $\mathrm{BCF}$ which is capable of employing for this purpose was found in the culture broth of Bacillus subtilis. As elucidating the properties of $\mathrm{BCF}$ may be more useful for isolating it, we tried carrying out this work first.

As a result, this substance (BCF) aroused our interest because it had no antimicrobial activity in itself, but enhanced the activity of HP against gram- 
negative bacteria and weakened the salt tolerance of Staphyloccus aureus; besides, $\mathrm{BCF}$ was unstable at acid $\mathrm{pH}$ though it was stable at alkaline $\mathrm{pH}$, and it was stable to heat. These properties were different from those of many antibiotics (Shoji et al., $1975 \mathrm{a}, \mathrm{b}, \mathrm{c}, \mathrm{d}$; Shoji et al., $1976 \mathrm{a}, \mathrm{b}, \mathrm{c}, \mathrm{d}, \mathrm{e}, \mathrm{f}, \mathrm{g}$; Shoji et al., 1977; Shoji et al., 1978; Shoji et al., 1980; Umezawa, 1967) which are produced by the genus Bacillus.

To our knowledge, therefore, there is no known substance identical with $\mathrm{BCF}$. Thus, $\mathrm{BCF}$ may be a new substance which is bacteriologically active.

\section{REFERENCES}

Shoji J., H. Hinoo, Y. Wakizaka, K. Koizumi and M. Mayama 1976 a Isolation of a new peptide antibiotic complex, B-43. J. Antibiotics, 29: 813-817

Shoji J., R. Sakazaki, Y. Wakisaka, K. Koizumi and M. Mayama 1975 a Isolation of a new peptide antibiotic complex 61-26. J. Antibiotics, 28: 129-131

Shoji J., T. Kato, K. Matsumoto, Y. Takahashi and M. Mayama $1976 \mathrm{~b}$ Production and isolation of cerexins C and D. J. Antibiotics, 29: 1281-1285

Shoji J., H. Hinoo, Y. Wakisaka, K. Koizumi, M. Mayama and Matsuura 1977 Isolation of two new plmyoyxin group antibiotics J. Antibiotics, 30: 1029-1034

Shoji J., H. Hinoo, Y. Wakisaka, K. Koizumi, M. Mgyama and S. Matsuura 1975 b Isolation of a new peptide actibiotic TL-119. J. Antibiotics, 28: 126-128

Shoji J., H. Hinoo, Y. Wakisaka, K. Koizumi, M. Mayama and S. Matsuura $1976 \mathrm{c}$ Isolation of a new peptide antibiotic, 339-29. J. Antibiotics, 29: 809-812

Shoji J., R. Sakazaki, Y. Wakisaka, K. Koizumi, M. Mayama and S. Matsuura 1975 c Isolation of galantins 1 and 2, water-soluble basic 3. J. Antibiotics, 28: 122-125

Shoji J., H. Hinoo, Y. Wakisaka, K. Koizumi, M. Mayama, S. Matsuura and K. Matsumoto $1975 \mathrm{~d}$ Isolation of two new related peptide antibiotics, cerexins A and B. J. Antibiotics, 28: $56-59$

Shoji J., H. Hinoo, Y. Wakisaka, K. Koizumi, M. Mayama, S. Matsuura and K. Matsumoto $1976 \mathrm{~d}$ Isolation of three new antibiotics, thiocillins 1,2 and 3 , related to micrococcin P. J. Antibiotics, 29: 366-374

Shoji J., H. Hinoo, Y. Wakisaka, K. Koizumi, M. Mayama, S. Matsuura and K. Matsumoto 1976 e Isolation of a new antibiotic 333-25, related to antibiotic EM 49. J. Antibiotics, 29: $516-520$

Shoji J., R. Sakazaki, Y. Wakisaka, K. Koizumi, H. Miwa, S. Matsuura and M. Mayama 1980 Isolation of octapetin D. J. Antibiotics, 33: 182-185

Shoji J., R. Sakazaki, Y. Wakisaka, K. Koizumi, M. Mayama, S. Matsuura and K. Matsumoto $1976 \mathrm{f}$ Isolation of brevistin, a new peptide antibiotic. J. Antibiotics, 29:375379

Shoji J., R. Sakazaki, Y. Wakisaka, K. Koizumi, M. Mayama, S. Matsuura and K. Matsumoto $1976 \mathrm{~g}$ Isolation of a new antibiotic, laterosporamine. J. Antibiotics, 29: 390-393

Shoji J., H. Hinoo, R. Sakazaki, T. Kato, Y. Wakisaka, M. Mayama H. Hiwa and S. Matsuura 1978 Isolation of tridecaptins A, B and C. J. Antibiotics, 31: 646-651

Tsutsumi M., K. Nishimura, K. Yasui, A. Matsuoka and T. Watanabe 1976 Synergistic action of cholate on some antimicrobial subsances. Shokuhin Eiseigaku Zasshi (J. Food Hyg. Soc. Jpn.) 17: 273-275

Tsutsumi M., K. Yasui, K. Isshiki and T. Watanabe 1977 Preservative effect of polyphosphates (Part 2). Action of hexametaphosphate on Escherichia coli. Shokuhin Eiseigaku Zasshi (J. Food Hyg. Soc. Jpn.) 18: 341-345 
Umezawa S. 1967 Khokinseibusshitsu, Baifukan, Tokyo (in Japanese)

Watanabe T., G. Hirata and M. Tsutsumi 1977 Bacterostatic technique by application of the synergism between sodium polyphosphate 1.67 $>\left(\mathrm{Na}_{2} \mathrm{O}+\mathrm{H}_{2} \mathrm{O}\right) / \mathrm{P}_{2} \mathrm{O}_{5}>\mathrm{O}$ and sodium cholate. Nihon Tokkyo No 858746 (in Japanese)

Watanabe T., M. Tsutsumi, K. Isshiki, G. Hirata 1979 New food preservative containing both A (either hexametaphosphate or ultraphosphate) and B (either glycerol monocaprate or glycerol monocaprylate). Tokkyo Koho Showa 54-32057 (in Japanese) 